УДК 378.147.091.33-027.22(4)

DOI https://doi.org/10.32782/apv/2021.6.18

\title{
Світлана ЧЕПУРНА
}

аспірантка кафедри педагогіки, психології й освітнього менеджменту імені професора Є. Петухова, Херсонський державний університет, вул. Університетська, 27, м. Херсон, Україна, 73003

ORCID: 0000-0002-2526-7313

Бібліографічний опис статті: Чепурна, С. (2021) Компаративний аналіз практико-орієнтованої підготовки майбутнього вчителя початкової школи в європейських країнах, Acta Paedagogica Volynienses, 6, 115-122, doi: https://doi.org/10.32782/apv/2021.6.18

\section{КОМПАРАТИВНИЙ АНАЛІЗ ПРАКТИКО-ОРІЄНТОВАНОЇ ПІДГОТОВКИ МАЙБУТНЬОГО ВЧИТЕЛЯ ПОЧАТКОВОЇ ШКОЛИ В ЄВРОПЕЙСЬКИХ КРАЇНАХ}

У статті розглянуто основні аспекти практико-орієнтованої підготовки майбутнього вчителя початкової школи у вітчизняних та закордонних закладах вищзӧ освіти. Проаналізовано оновлені стандарти вищої освіти спеціальності 013 Початкова освіта, в яких визначено вимоги до професійної підготовки здобувачів вищої освіти та окреслено перелік необхідних компетентностей, якими повинен володіти майбутній педагог. Акцентовано увагу на актуальності та важливості питання практичної підготовки у сучасних закладах вищої освіти.

Визначено, щз з погляу часової організації педагогічна практика може бути неперервною або інтенсивною (блочною), і розкрито характерологічні особливості ичх видів педагогічної практики. Прикладами неперервної практичної підготовки є США та Велика Британія, інтенсивної-Німеччина.

У статті схарактеризовано закордонний та вітчизняний досвід організації педагогічної практики та окреслено основні ї̈ види для здобувачів вищої освіти спеціальності 013 Початкова освіта, здійснено їх порівняльний аналіз. Принциии проходження педагогічної практики в Украӥні розглянуто на прикладі Херсонського державного університету. Висвітлено специфіку організації та проведення педагогічної практики у закордонних закладах вищої освіти, зокрема Німеччині та Фінляндї, оскільки освітня система циих країн протягом багатьох років являється однією з найуспішніших у Свропі та світі.

Визначено, щуо європейський досвід професійної та практичної підготовки майбутніх учителів початкової школи відображає сучасні освітні вимоги, які полягають у формуванні компетентного та висококваліфікованого професіонала, який здатен реагувати на виклики суспільства та орієнтуватися у швидкоплинному потоці інформації.

Вивчення прогресивних ідей, досвіду означених краӥн щзодо практико-орієнтованої підготовки майбутнього вчителя початкової школи є важливим для впровадження найкращчого європейського досвіду в освітній процес украӥнських закладів вищої освіти.

Ключові слова: практико-орієнтована підготовка, педагогічна практика, майбутній учитель початкової школи, Німеччина, Фінляндія, Україна.

\section{Svetlana CHEPURNA}

Postgraduate Student at the Department of Pedagogy, Psychology and Educational Management named by Professor E. Petukhov, Kherson State University, University str., 27, Kherson, Ukraine, 73003

ORCID: 0000-0002-2526-7313

To cite this article: Chepurna, S. (2021) Komparatyvnyi analiz praktyko-oriientovanoi pidhotovky maibutnoho vchytelia pochatkovoi shkoly $\mathrm{v}$ yevropeiskykh krainakh [The comparative analysis of practical-oriented training of the future primary school teacher in European countries]. Acta Paedagogica Volynienses, 6, 115-122, doi: https://doi.org/10.32782/apv/2021.6.18

\section{THE COMPARATIVE ANALYSIS OF PRACTICAL-ORIENTED TRAINING OF THE FUTURE PRIMARY SCHOOL TEACHER IN EUROPEAN COUNTRIES}

The article considers on the main aspects of practice-oriented training of future primary school teachers in domestic and foreign higher education institutions. The updated standards of higher education in the specialty 013 Primary Education are analyzed, which define the requirements for professional training of applicants for higher education and outline the list of necessary competencies that a future teacher must have. Emphasis is placed on the relevance and importance of practical training in modern higher education institutions. 
It is determined that from the point of view of temporal organization pedagogical practice can be continuous or intensive (block) and the characterological features of these types of pedagogical practice are revealed. Examples of continuous practical training are the United States and Great Britain, intensive is Germany.

The article characterizes the foreign and domestic experience of the organization and the main types of pedagogical practice of applicants for higher education in the specialty 013 Primary education, their comparative analysis. The principles of pedagogical practice in Ukraine are considered by the example of Kherson State University. The specifics of organizing and conducting pedagogical practice in foreign higher education institutions, in particular in Germany and Finland, are highlighted, as the educational system of these countries has been one of the most successful in Europe and the world for many years.

It is determined that the European experience of professional and practical training of future primary school teachers reflects on modern educational requirements, which are to form a competent and highly qualified future professional who is able to respond to societal challenges and navigate the rapid flow of information.

The study of progressive ideas, the experience of these countries in practice-oriented training of future primary school teachers is important for the implementation of the best European experience in the educational process of Ukrainian higher education institutions.

Key words: practice-oriented training, pedagogical practice, future primary school teacher, Germany, Finland, Ukraine.

Актуальність проблеми. Сучасний випускник закладу вищої освіти має бути готовим до використання всього спектру здобутих за період навчання у ЗВО компетентностей та вміти швидко реагувати і вирішувати майбутні професійні завдання у самостійній педагогічній діяльності.

Питання практичної підготовки майбутнього вчителя початкової школи завжди викликало зацікавлення 3 боку педагогів та викладачів закладів вищої освіти. Оволодіння професійними компетентностями - це неперервний процес формування та удосконалення педагогічних умінь здобувачів вищої освіти на різних етапах, враховуючи навчання в закладі освіти, практичну підготовку під час проходження педагогічної практики та самостійну професійну діяльність після закінчення закладу освіти.

Аналіз останніх досліджень і публікацій. Питанню організації та проходження педагогічної практики велика увага приділялася в роботах О.А. Абдулліної, Л.А. Аврамчук, І.Ф. Харламова, О.Є. Блінової, І.О. Котик, C.I. Архангельського, Л.С. Нечепоренко, А.І. Піскунова, Р.П. Попелюшко та ін.

Саме під час проходження педагогічної практики здобувач вищої освіти повинен навчитися застосовувати особистий та накопичений досвід, контролювати ефективність своїх дій, вміти доцільно впроваджувати методи та засоби навчання і виховання молодших школярів, які б відповідали їх віковому і фізіологічному розвитку та задовольняли освітні потреби.

Актуальним є твердження, що підготовка майбутнього вчителя початкової школи не може обмежуватися трансляцією багажу теоретич- них знань. Тому багато сучасних українських та зарубіжних досліджень, присвячених педагогічній освіті, ідентичні в питанні подолання бар'єру між теоретичною та практичною підготовкою здобувачів вищої освіти педагогічних спеціальностей. Адже під час практики не тільки накопичується початковий професійний досвід, а й відбувається становлення особистісно-професійної позиції, неповторний досвід проживання педагогічних ситуацій та вирішення педагогічних завдань.

У країнах зарубіжжя широкої популярності набули науково-дослідні інститути з вивчення та дослідження проблеми підготовки вчителя. Наприклад, у Німеччині - Інститут теорії та методики підготовки учителів, у Чехії Інститут підготовки та підвищення кваліфікації учителів та Інститут вивчення особистості вчителя, у Польщі - Інститут навчання вчителів (Прохорова, 2015: 56-58).

В Україні ж традиційно займаються підготовкою майбутнього вчителя початкових класів заклади вищої освіти. На жаль, до початку освітньої реформи в навчальних планах здобувачів вищої освіти спеціальності 013 Початкова освіта дуже мало часу відводилося на проходження педагогічної практики. I тільки iз затвердженням та введенням в дію нового стандарту вищої освіти за спеціальністю 013 Початкова освіта для першого (бакалаврського) рівня вищої освіти у 2021 році (Стандарт, 2021) кількість годин, відведених на практичну підготовку майбутніх педагогів, значно збільшилася (мінімальний обсяг практик зі спеціальності - $15 \%$ обсягу освітньої програми). 
Метою дослідження $є$ здійснення компаративного аналізу практико-орієнтованої підготовки майбутніх учителів початкової школи України, Німеччини та Фінляндії.

Виклад основного матеріалу. Розглянемо принципи проходження педагогічної практики в Україні на прикладі Херсонського державного університету. Професійна підготовка майбутніх учителів початкової школи здійснюється на педагогічному факультеті. Аналіз освітньопрофесійної програми 3 підготовки здобувачів вищої освіти за спеціальністю 013 Початкова освіта засвідчує, що для практичної підготовки майбутніх фахівців на факультеті діє два види педагогічної практики: навчальна та виробнича педагогічні практики.

Практична підготовка майбутніх педагогічних працівників на факультеті є неперервною протягом усього терміну навчання. Вона починається 3 першого року навчання, тривалість кожного виду практики поступово збільшується у зв'язку з ускладненням завдань практики і поглибленням теоретичної та методичної підготовки здобувачів освіти.

Практична підготовка майбутніх учителів початкової школи Херсонського державного університету включає такі види педагогічних практик, які окреслено на рис. 1.

Практична підготовка здобувачів освіти педагогічного факультету починається вже 3 першого року навчання. У другому семестрі здобувачі проходять навчальну практику протягом 2 тижнів, на яку відводиться 3 кредити ЄКТС, що становить 90 годин. Ця практика $\epsilon$ специфічною тим, що сприяє формуванню мотивації до майбутньої професійної діяльності та знайомить практиканта зі специфікою майбутньої професії, а також сприяє формуванню природознавчої компетентності майбутніх учителів початкової школи. Предметом навчальної практики є освітній процес закладу загальної середньої освіти та природниче і соціокультурне середовище (парки міста Херсон, Агробіостанція - ботанічний сад ХДУ, Нижньодніпровські плавні, узбережжя Чорного моря, Національний природничий парк «Джарилгач», Олешківські піски, заповідник «Асканія-Нова», Херсонський краєзнавчий музей) як умова формування мотивації до майбутньої професії та природознавчої компетенції майбутніх педагогів. Метою цього виду практичної підготовки майбутніх учителів початкової школи $є$ закріплення та поглиблення теоретичних знань із циклу природничо-наукової підготовки; набуття поглиблених знань про флору та фауну міста Херсон; формування позитивної мотивації до майбутнього фаху; знайомство 3 різними видами і типами закладів освіти (Бальоха, 2017).

Навчальна (психолого-педагогічна) практика здобувачів здійснюється на другому та третьому курсах навчання. Організовується такий вид навчальної практики на базах закладів загальної середньої освіти, з якими керівництво факультету уклало угоду про співпрацю. На другому курсі відповідно до навчального плану на цей вид практики відведено 1,5 кредиту ЄКТС, що становить 45 годин. Тривалість психолого-педагогічної практики становить один тиждень. На третьому курсі здобувачі

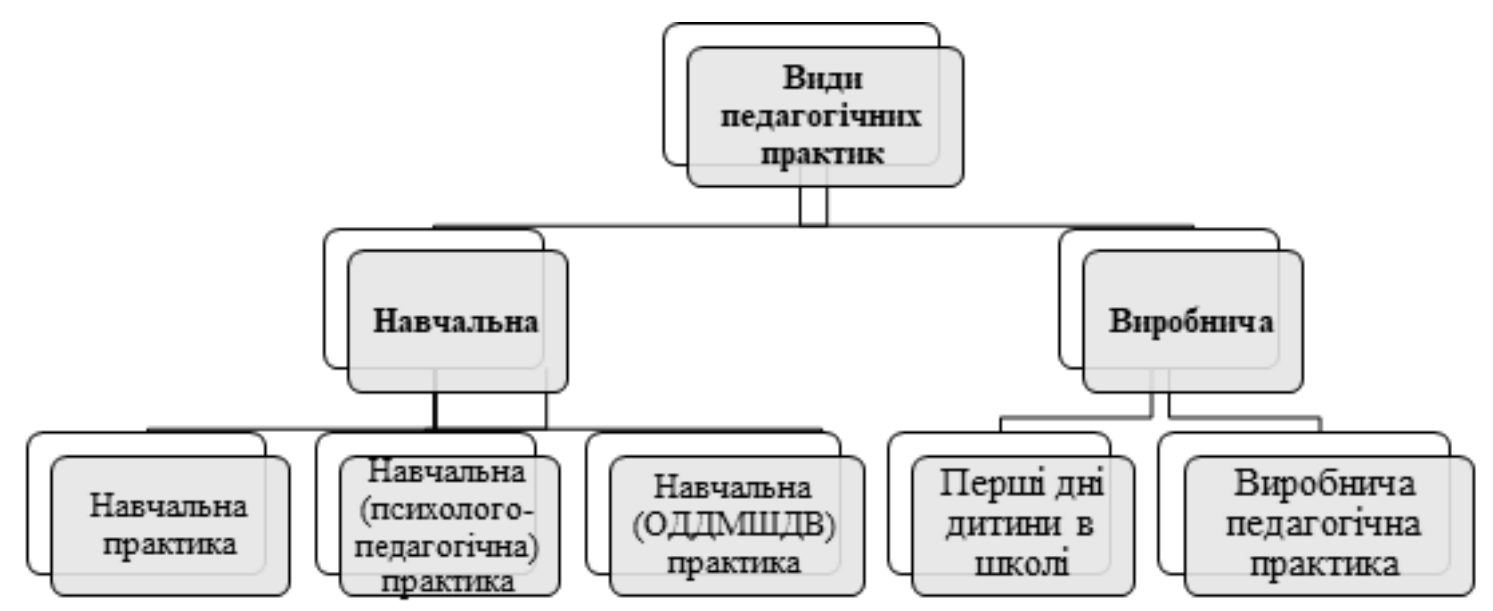

Рис. 1. Види педагогічних практик Херсонського державного університету педагогічного факультету 
освіти проходять практику в закладах освіти протягом двох тижнів, на яку відведено 3 кредити ЄКТС, що становить 90 годин.

Також здобувачі другого курсу проходять навчальну (організачія дозвілля дітей дошкільного та молодшого шкільного віку) практику. Цей вид практичної підготовки серед них найулюбленіший, тому що організовується на базі спортивно-оздоровчого табору «Буревісник». Здобувачі-практиканти перебувають на базі практики протягом одного тижня. Специфікою цієї практики $є$ те, що здобувачі освіти удосконалюють навички організації учнівського колективу. Під час практичної діяльності практиканти беруть участь у таких цікавих формах роботи, як: квести, інсценування казок, організація КВК, танцювальні та пісенні конкурси; проявляють творчий підхід до представлення своєї спеціальності. Ця практика також дуже цінна в процесі адаптації здобувачів до ЗВО та сприяє згуртуванню академічних груп.

Здобувачі вищої освіти четвертого року навчання у сьомому семестрі проходять виробничу педагогічну практику, яка має активний характер та складається 3 двох етапів:

1. «Перші дні дитини в школі» (1 тиждень). Метою цього етапу практичної підготовки $\epsilon$ ознайомлення здобувачів освіти із своєрідністю періоду адаптації дитини до нових умов закладу освіти протягом першого тижня іiї перебування в школі;

2. Виробнича практика (6 тижнів). Практиканти беруть безпосередню участь в освітньому процесі початкової школи. Поглиблюють та удосконалюють свої професійні знання та навички.

Перед проведенням кожного виду практичної підготовки на педагогічному факультеті Херсонського державного університету відбувається організаційна робота зі здобувачами, яка проводиться 3 метою ознайомлення практикантів iз завданнями практики, видами та формами роботи, а також критеріями оцінювання. Керівником практик факультету перед початком кожної практики проводяться настановні конференції.

Під час педагогічної практики здобувачі вищої освіти мають можливість ознайомитися 3 майбутньою професійною діяльністю, застосувати теоретичні знання в межах самостійної педагогічної роботи, а також знайти місце для майбутнього працевлаштування.

3 погляду часової організації педагогічна практика може бути неперервною або інтенсивною (блочною) (таблиця 1) (Блинов, 2004: 41-53).

Прикладами неперервної практичної підготовки є США та Велика Британія, інтенсивної Німеччина.

Отже, розглянемо специфіку проведення та організації педагогічної практики в закладах вищої освіти за кордоном.

Наприклад, у закладах вищої освіти Німеччини під час проходження педагогічної практики здобувачі освіти щотижня відвідують шкільні уроки, після чого обговорюють та аналізують їх із викладачем. Професійна практична підготовка майбутнього учителя початкової школи Німеччини здійснюється в декілька етапів:

- практика на професійну здатність (Eignungspraktikum);

- ознайомлювальні (орієнтувальні) практики (Orientierungspraktikum);

- професійна практика (Berufsfeldpraktikum);

- практичний семестр (Praxissemester);

- педагогічне стажування - референдаріат (Бобраков, 2011: 246).

\section{Види педагогічної практики з погляду часової організації (за В.І. Бліновим)}

\begin{tabular}{|c|c|}
\hline Неперервна практична підготовка & Інтенсивна (блочна) практична підготовка \\
\hline $\begin{array}{l}\text { Передбачає поступовенабуттяздобувачами уміньтанавичок } \\
\text { педагогічної діяльності, починаючи з тих, які не вимагають } \\
\text { фундаментальної підготовки й можуть реалізуватися } \\
\text { на молодших курсах: організаційні, комунікативні, } \\
\text { дидактичні, діагностичні та інші уміння та навички, які } \\
\text { реалізуються у процесі позакласної діяльності в школі } \\
\text { або в роботі літнього оздоровчого табору. Після чого на } \\
\text { основі закріплених знань та вмінь розвивається комплекс } \\
\text { дидактичних умінь, які необхідні для реалізації функцій } \\
\text { учителя початкової школи. }\end{array}$ &  \\
\hline
\end{tabular}


Найперший етап педагогічної практики у Німеччині зазвичай відбувається ще до вступу в заклад вищої освіти та передбачає знайомство здобувачів зі специфікою майбутньої професійної діяльності та занурення в освітній процес школи. Ця практика має пасивний характер та відбувається у формі спостереження за професійною діяльністю учителя початкової школи, вивчення нормативно-правової документації, бесід із школярами та педагогами. Цей вид практичної підготовки майбутнього здобувача педагогічного закладу вищої освіти виступає передумовою вступу до нього та не $\epsilon$ компонентом освітньої програми в системі підготовки бакалаврів та магістрантів.

Ознайомлювальні (орієнтувальні) практики - цей вид $\epsilon$ початковим етапом практичної підготовки здобувачів першого (бакалаврського) рівня вищої освіти. Він поділяється на три окремих види практики, які здобувачі освіти зазвичай проходять у першому та другому семестрах навчання. Практиканти перебувають на базах практики у відведений для цього час кожного дня, відвідують уроки у закріпленому за ними класі, позашкільні заходи, шкільні методичні наради (Бобраков, 2011: 247). За результатами проходження практики здобувачі освіти готують письмовий звіт із практики, в якому вони описують свої враження або труднощі, які виникали у процесі практичної підготовки.

Професійно-педагогічною діяльністю здобувачів освіти на базах практики керують досвідчені вчителі та методисти протягом усього періоду проходження практики.

Наступним видом практичної підготовки бакалаврів у Німеччині є професійна практика. Вона може бути організована як у школі, так і в позашкільних закладах та передбачає формування у здобувачів освіти принципів організації виховної діяльності вчителя початкової школи. Ця практика передбачає поглиблення та узагальнення теоретичних знань із психології та педагогіки, формування умінь організації дитячого колективу, навичок спілкування з різними віковими групами дітей, ознайомлення із функціональними обов'язками вчителя, формування практичних умінь та навичок впровадження та використання інноваційних методів та технологій навчання.

Останнім видом практичної підготовки у Німеччині $є$ практичний семестр
(Praxissemester), що проходить в другому або третьому семестрах магістерської фази. Базами практики є заклади загальної середньої освіти школи, ліцеї, гімназії тощо. Керівниками цього виду практики $є$ викладачі-методисти кафедр фахових методик. Здобувачі освіти в межах практичної підготовки знайомляться зі специфікою освітньої діяльності вчителя, вивчають особливості навчальних планів, процес складання розкладу уроків, спостерігають за проведенням уроків вчителями, а також самі готують та проводять уроки.

Після завершення практичної підготовки здобувач освіти складає два державних іспити. Перший - орієнтовано на перевірку знань із декількох предметів у вигляді домашньої наукової роботи, контрольної роботи або ж усного екзамену; другий - перевірка готовності до практичної діяльності майбутнього вчителя початкової школи. Цей екзамен передбачає проведення уроку та вирішення педагогічних ситуацій. Державна атестація в Німеччині має накопичувальний характер (Скоробогатова, 2010).

Також нас зацікавила організація педагогічної практики у Фінляндії, адже освітня система цієї країни протягом багатьох років являється однією з найуспішніших у Свропі та світі.

Професійна підготовка майбутніх учителів початкової школи (1-6 класи) здійснюється в університетах на факультетах педагогічної освіти (120 кредитів для бакалаврської програми та 160 кредитів для магістерської програми). Особлива увага приділяється студентській практиці (Орлов, 2015: 149-156).

Проведення педагогічної практики у фінській системі освіти грунтується на засадах практико-орієнтованого підходу. Практична підготовка фінських здобувачів освіти базується на принципі наступності та відбувається впродовж всього періоду навчання. Педагогічна практика здійснюється в декілька етапів, зображених на рис. 2. (Зарубіжний досвід, 2017).

Майбутні вчителі відвідують базові університетські школи із самого початку навчання й поступово знайомляться 3 викладацькою діяльністю на початковій ланці загальноосвітньої школи (вступна практика). Після вступної практики організовується спочатку основна практика, а потім практика в базових університетських школах (так звана «польова 


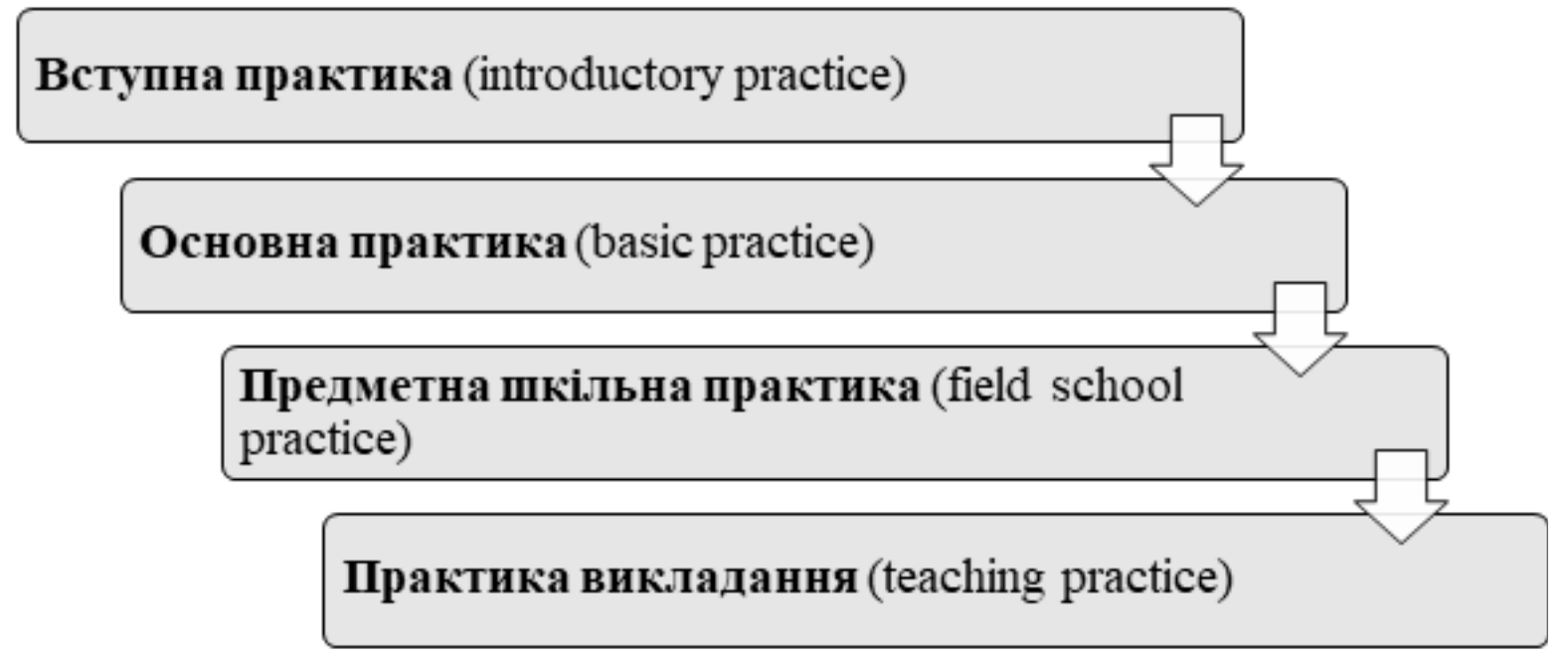

Рис. 2. Етапи здійснення педагогічної практики у Фінляндії

практика»), і наприкінці - практика викладання (Орлов, 2015: 152).

Під час основної практики здобувачі знайомляться $з$ особливостями педагогічної професії, з формами навчання, методами контролю й оцінювання навчальних досягнень учнів. Вони планують, проводять та оцінюють уроки.

Що нас найбільше зацікавило в організації цього виду практики, так це те, що він супроводжується створенням студентами портфоліо, що містить навчальний матеріал, який відображає матеріали за результатами проведених уроків у школі.

Основна мета педагогічного портфоліо продуктивне забезпечення відповідних методів роботи для удосконалення педагогічного викладання у школі. У педагогічній підготовці майбутніх учителів початкових класів багато університетів Фінляндії використовують системи заохочень (meriting system) (Зарубіжний досвід, 2017: 44).

«Польова» шкільна практика і викладацька навчальні періоди, які можуть бути об'єднані, а тому у здобувачів освіти з'являються можливості розширення поглядів на професію вчителя, оволодіння різноманітними методами i прийомами навчання. Здобувачі працюють в одному класі з учителем-керівником практики і несуть відповідальність за цей клас протягом усього періоду перебування в закладі освіти.

Під час педагогічної практики здобувачі також займаються науково-дослідною роботою, що має позитивний вплив на якість виконання магістерських робіт.
Виготовлення портфоліо та впровадження науково-дослідної роботи сприяє ефективності педагогічної практики та теоретичного навчання студентів, що розглядається університетами як повноцінний стимул для кар'єрного зростання в межах університету та майбутньої роботи у школі (Зарубіжний досвід, 2017: 44).

Практична підготовка майбутніх педагогів Фінляндії проходить не тільки в муніципальних школах, але й у «Педагогічних тренувальних школах» при університетах Фінляндії. У Фінляндії є близько 13 педагогічних тренувальних шкіл (Рованіемі, Оулу, Каяані, Йоенсуу, Ювяскуля, Васава, Темпере, Савонлінна, Раума, Хамеенлінна, Турку, Віккі та Хельсінки). «Педагогічні тренувальні школи» виконують чотири функції. Перша - забезпечення набуття педагогічного досвіду близько 3000 студентами-стажерами на рік. Друга полягає у забезпеченні супервізора (supervision) і тьюторства (tutoring) для студентів-стажерів. Третя - у здійсненні дослідження та розвитку педагогічних інновацій. Тоді як четверта функція полягає у забезпеченні педагогічної підготовки у процесі навчання (in-service training for teachers) (Зарубіжний досвід, 2017: 67).

Таким чином, вивчення та аналіз особливостей проведення, організації та змісту педагогічної практики майбутніх учителів початкової школи Німеччини та Фінляндії дали змогу здійснити порівняльний аналіз цього педагогічного явища та проведення практичної підготовки в українських закладах вищої освіти (таблиця 2). 
Таблиця 2

Порівняльний аналіз практичної підготовки майбутніх учителів початкової школи Німеччини, Фінляндії, України

\begin{tabular}{|c|c|c|c|c|}
\hline $\begin{array}{c}\text { Назва } \\
\text { країни }\end{array}$ & $\begin{array}{c}\text { Вид } \\
\text { педагогічної } \\
\text { практики }\end{array}$ & $\begin{array}{c}\text { Початок } \\
\text { та тривалість } \\
\text { проходження } \\
\text { практики }\end{array}$ & $\begin{array}{c}\text { Наявність } \\
\text { і тривалість } \\
\text { стажування }\end{array}$ & Зміст проходження педагогічної практики \\
\hline Україна & $\begin{array}{l}\text { Неперервна } \\
\text { практика }\end{array}$ & $\begin{array}{l}\text { Починається } \\
3 \text { першого року } \\
\text { та відбувається } \\
\text { в п р о д о в ж } \\
\text { усього періоду } \\
\text { навчання }\end{array}$ & $\begin{array}{l}\text { В і д с у т н є } \\
\text { стажування }\end{array}$ & $\begin{array}{l}\text { Проходження педагогічної практики має на меті } \\
\text { активізацію та поглиблення теоретичних знань } \\
\text { у процесі проходження практики. Формування умінь } \\
\text { та навичок здійснення майбутньої професійної } \\
\text { діяльності в закладах загальної середньої освіти. } \\
\text { Оволодіння новітніми формами та методами роботи } \\
\text { з учнями початкових класів. Впровадження в освітній } \\
\text { процес сучасних інформаційно-комунікаційних } \\
\text { технологій навчання. Здійснення науково-дослідного } \\
\text { дослідження в межах написання кваліфікаційних робіт } \\
\text { першого (бакалаврського) та другого (магістерського) } \\
\text { рівнів вищої освіти. }\end{array}$ \\
\hline Німеччина & $\begin{array}{l}\text { Інтенсивна } \\
\text { ( б л о ч н а ) } \\
\text { практика }\end{array}$ & $\begin{array}{l}\text { Починається } \\
3 \text { першого року } \\
\text { навчання }\end{array}$ & $\begin{array}{l}\text { Н а я в н е } \\
\text { педагогічн е } \\
\text { стажування - } \\
\text { референдаріат }\end{array}$ & $\begin{array}{l}\text { Проходження педагогічної практики має на } \\
\text { меті адаптацію здобувачів освіти до майбутньої } \\
\text { професії вчителя початкової школи. Практиканти } \\
\text { усвідомлюють і оцінюють правильність вибору } \\
\text { майбутньої професії. Зміст практичної підготовки } \\
\text { спрямований на збільшення самостійності здобувачів. } \\
\text { Практична підготовка має на меті відвідування шкіл, } \\
\text { позашкільних заходів та методичних об'єднань } \\
\text { учителів, проведення уроків, вивчення структури } \\
\text { закладу освіти, аналіз освітнього процесу школи, } \\
\text { накопичення педагогічного досвіду. }\end{array}$ \\
\hline Фінляндія & $\begin{array}{l}\text { Неперервна } \\
\text { практика }\end{array}$ & $\begin{array}{l}\text { Починається } \\
3 \text { першого року } \\
\text { та відбувається } \\
\text { в п р о д о в ж } \\
\text { усього періоду } \\
\text { навчання }\end{array}$ & $\begin{array}{l}\text { В і д с у т н } \epsilon \\
\text { стажування }\end{array}$ & $\begin{array}{l}\text { Проведення педагогічної практики грунтується на } \\
\text { засадах практико-орієнтованого підходу. Практична } \\
\text { підготовка має на меті відвідування муніципальних } \\
\text { та педагогічних тренувальних шкіл при університетах } \\
\text { із метою активізації теоретичних знань, набуття } \\
\text { педагогічного досвіду, дослідження та впровадження } \\
\text { педагогічних інновацій. Під час проходження } \\
\text { педагогічної практики здобувачі освіти акцентують } \\
\text { увагу на оволодіння різноманітними методами } \\
\text { та прийомами навчання молодших школярів. Також } \\
\text { здобувачі здійснюють науково-дослідну роботу } \\
\text { в межах написання магістерського дослідження. }\end{array}$ \\
\hline
\end{tabular}

Висновки. Аналіз практико-орієнтованої підготовки майбутнього вчителя початкової школи у вітчизняних та закордонних закладах вищої освіти дає підстави стверджувати, що педагогічна практика інтегрує теоретичну та практичну складові частини підготовки здобувачів вищої освіти та є невід'ємним і обов'язковим компонентом у підготовці майбутнього вчителя початкової школи як українських, так i закордонних закладів вищої освіти. А ii зміст спрямовано на самостійне проведення уроків, виховних заходів, вивчення особистості учня та дитячого колективу, тісну співпрацю 3 учнями та їхніми батьками, участь у системі шкільного самоврядування, планування та аналіз власної професійнопедагогічної діяльності. Вивчення європейського досвіду щодо практико-орієнтованої підготовки майбутнього вчителя початкової школи є важливим для впровадження найкращого досвіду в освітній процес закладів освіти України.

\section{ЛІТЕРАТУРА:}

1. Бальоха А.С. Навчальна (природнича) практика: методичні рекомендації для студентів спеціальностей 012 Дошкільна освіта, 013 Початкова освіта денної форми навчання. Херсон : ТОВ «Борисфен-про», 2017. 34 с.

2. Блинов В.И. Педагогическая подготовка будущих учителей: прагматика перспективы // Педагогическая наука и практика: перспективы. Сб.науч.статей. Вып. 2. Москва : ИОО МОН РФ, 2004. 202 с. С. 41-53. 
3. Бобраков С.В. Зміст та форми організації педагогічної практики у процесі підготовки майбутніх вчителів у ВНЗ Німеччини / Вісник Луганського національного університету імені Тараса Шевченко (педагогічні науки). № 15 (226). Луганськ: Луганський національний університет імені Тараса Шевченко, 2011. С. 244-251. URL: https://dspace.lgpu.org/bitstream/123456789/287/1/№\%2015_226_2011_ПН_Ч.\%202.pdf\#page=245

4. Зарубіжний досвід професійної підготовки педагогів : аналітичні матеріали / Авшенюк Н.М., Дяченко Л.М., Котун К.В., Марусинець М.М., Огієнко О.І., Сулима О.В., Постригач Н.О. Київ : ДКС «Центр», 2017. 83 с.

5. Орлов Л.В., Печинкина О.В. Современное педагогическое образование в Финляндии и Швеции: структура и содержание / Л.В.Орлов, О.В.Печинкина // Педагогика. Психология, 2015. С. 149-156.

6. Прохорова И.К. Роль педагогической практики в формировании профессиональных компетенций будущих педагогов / Педагогические науки. Евразийский союз ученых. № 11 (20). 2015. С. 56-58.

7. Скоробогатова М.Р. Развитие системы подготовки учителей начальных классов в Украине (вторая половина XX столетия): дис. ... канд. пед. наук: 13.00.01 / Скоробогатова мария Растиславовна. Симферополь, 2010. 265 с.

8. Стандарт вищої освіти України для першого (бакалаврського) рівня вищої освіти спеціальності 013 Початкова освіта. Наказ Міністерства освіти і науки України від 23.03.2021 № 357. URL: https://mon.gov.ua/ua/osvita/ visha-osvita/naukovo-metodichna-rada-ministerstva-osviti-i-nauki-ukrayini/zatverdzheni-standarti-vishoyi-osviti.

\section{REFERENCES:}

1. Balokha A.S. (2017) Navchalna (pryrodnycha) praktyka: metodychni rekomendatsii dlia studentiv spetsialnostei 012 Doshkilna osvita, 013 Pochatkova osvita dennoi formy navchannia [Educational (natural) practice: methodical recommendations for students of specialties 012 Preschool education, 013 Primary education full-time]. Kherson : TOV «Borysfen-pro», 2017.34 p. (in Ukrainian)

2. Blynov V.Y. (2004) Pedahohycheskaia podhotovka budushchykh uchytelei: prahmatyka perspektyvu [Pedagogical training of future teachers: a pragmatics perspective] // Pedahohycheskaia nauka y praktyka: perspektyvy. Sb.nauch.statei. Vyp. 2. Moskva : YOO MON RF. pp. 41-53. (in Ukrainian)

3. Bobrakov S.V. (2011) Zmist ta formy orhanizatsii pedahohichnoi praktyky u protsesi pidhotovky maibutnikh vchyteliv u VNZ Nimechchyny [Content and forms of organization of pedagogical practice in the process of training future teachers in German universities] / Visnyk Luhanskoho natsionalnoho universytetu imeni Tarasa Shevchenko (pedahohichni nauky). № 15(226). Luhansk : Luhanskyi natsionalnyi universytet imeni Tarasa Shevchenkov. pp. 244-251. (in Ukrainian)

4. Zarubizhnyi dosvid profesiinoi pidhotovky pedahohiv : analitychni materialy [Foreign experience of professional training of teachers: analytical materials] / Avsheniuk N.M., Diachenko L.M., Kotun K.V., Marusynets M.M., Ohiienko O.I., Sulyma O.V., Postryhach N.O. Kyiv : DKS «Tsentr», 2017. 83 p. (in Ukrainian)

5. Orlov L.V., Pechynkyna O.V. (2015) Sovremennoe pedahohycheskoe obrazovanye v Fynliandyy y Shvetsyy: struktura y soderzhanye [Modern teacher education in Finland and Sweden: structure and content] // Pedahohyka. Psykholohyia. pp. 149-156. (in Russian)

6. Prokhorova Y.K. (2015) Rol pedahohycheskoi praktyky $\mathrm{v}$ formyrovanyy professyonalnukh kompetentsyi budushchykh pedahohov [The role of pedagogical practice in the formation of professional competencies of future teachers] / Pedahohycheskye nauky. Evrazyiskyi soiuz uchenykh. № 11(20). pp. 56-58. (in Russian)

7. Skorobohatova M.R. (2010) Razvytye systemu podhotovky uchytelei nachalnykh klassov v Ukrayne (vtoraia polovyna KhKh stoletyia) [Development of the system of training primary school teachers in Ukraine (second half of the 20th century)]: dys...kand. ped. nauk: 13.00.01 / Skorobohatova maryia Rastyslavovna. Symferopol. 265 p. (in Russian)

8. Standart vyshchoi osvity Ukrainy dlia pershoho (bakalavrskoho) rivnia vyshchoi osvity spetsialnosti 013 Pochatkova osvita [Standard of higher education of Ukraine for the first (bachelor's) level of higher education in specialty 013 Primary education]. Nakaz Ministerstva osvity i nauky Ukrainy vid 23.03.2021 № 357. (in Ukrainian). 